\title{
Evaluasi Penerapan Metode Penyuluhan Perikanan Praktik Akhir di Kabupaten Majalengka dan Kota Banjar, Provinsi Jawa Barat
}

\author{
[Evaluation of the Final Practice Application of Fisheries Extension Methods in \\ Majalengka Regency and Banjar City, West Java]
}

Ina Restuwati, Aan Hermawan

Program Studi Penyuluhan Perikanan Politeknik Ahli Usaha Perikanan Jalan Cikaret Nomor 2 Bogor Selatan, Kota Bogor 16132

\begin{abstract}
Abstrak
Evaluasi dengan model Context, Input, Process, and Product (CIPP) dilakukan untuk mengevaluasi Praktik Akhir (PA) taruna semester akhir pada Sekolah Tinggi Perikanan Jurusan Penyuluhan Perikanan meliputi proses penelitian kaji terap dengan metode penyuluhan berupa kolam percontohan (dempond), demonstrasi cara (demcar) serta pendampingan peran dan fungsi kelompok dalam meningkatkan kualitas pengelolaan kelompok sesuai dengan usaha perikanan yang dilakukan oleh pelaku utama. Adanya permasalahan mengenai rendahnya pemahaman tentang inovasi teknologi baru perikanan, pengelolaan dan manajemen bisnis perikanan serta fungsi dan peran kelompok menjadikan taruna harus mempunyai perencanaan yang matang dan tepat dalam memilih metode penyuluhan yang akan dilaksanakan. Penelitian ini bertujuan untuk menilai dan mengukur komponen context (konteks), input (masukan), process (proses), dan product (produk, output dan dampak) praktik akhir, serta menyusun konsep rekomendasi untuk perbaikan (improve) penerapan metode penyuluhan perikanan praktik akhir taruna. Penelitian dilakukan di Kabupaten Majalengka dan Kota Banjar, Provinsi Jawa Barat dengan jumlah responden sejumlah 94 orang pelaku utama. Hasil evaluasi menunjukkan bahwa komponen konteks, input, dan proses secara umum telah berjalan dengan baik. Namun terdapat kekurangan pada komponen produk sebagai hasil kegiatan yang diprogramkan. Sehingga perlu pendampingan secara intensif dan berkala oleh penyuluh perikanan dengan cara mengaktifkan peran dan fungsi kelompok serta pendampingan secara berkelanjutan dalam penerapan teknologi baru perikanan. Rekomendasi penelitian ini adalah perlu adanya peningkatan keterlibatan responden dalam tahap identifikasi, penentuan tujuan, maupun pengambilan keputusan, serta pentingnya sosialisasi regulasi perikanan dan pendampingan intensif pasca program praktik akhir dari penyuluh perikanan terkait.
\end{abstract}

Kata Kunci: evaluasi CIPP; praktik akhir; metode penyuluhan perikanan

\section{Abstract}

Evaluation with the Context, Input, Process, and Product (CIPP) model was carried out to evaluate the final practice (PA) of final semester cadets at the Fisheries College Department of Fisheries Extension, including a research process using extension methods in the form of a pilot pond (dempond), demonstration methods (demcar) as well as assisting the role and function of the group in improving the quality of group management in accordance with the fisheries business carried out by the main actors. The existence of problems regarding the low understanding of new fisheries technology innovations, fisheries business management and management as well as the functions and roles of groups make cadets must have careful and precise planning in choosing the extension methods to be implemented. This study aims to assess and measure the components of the context (context), input (input), process (process), and product (product, output and impact) of the final practice, as well as formulate the concept of recommendations for improvement (improve) the application of final practice fisheries extension methods. cadets. The research was conducted in Majalengka Regency and Banjar City, West Java Province with 94 respondents as the main actors. The results of the evaluation show that the context, input, and 
process components in general have worked well. However, there are deficiencies in the product components as a result of programmed activities. So it needs intensive and periodic assistance by fisheries extension agents by activating the roles and functions of groups as well as ongoing assistance in the application of new fisheries technology. The recommendation of this study is that there is a need to increase the involvement of respondents in the identification, goal setting, and decision-making stages, as well as the importance of socialization of fisheries regulations and intensive assistance after the final practice program of related fisheries extension agents.

Keywords: CIPP evaluation; final practice; fisheries extension methods

Penulis Korespondensi

Ina Restuwati | Email: restuina@gmail.com

\section{PENDAHULUAN}

Lulusan taruna Sekolah Tinggi Perikanan Jurusan Penyuluhan Perikanan merupakan calon penyuluh perikanan yang diharapkan juga dapat menjadi wirausaha andal di lapangan dan menjadi teladan bagi pelaku utama dan pelaku usaha perikanan. Salah satu syarat kelulusan taruna tersebut melalui karya ilmiah yang dihasilkan dari pelaksanaan Praktik Akhir (PA). Taruna diarahkan agar mampu melakukan kaji terap melalui praktik kegiatan penyuluhan perikanan, dengan menggunakan metode penyuluhan yang telah diajarkan di kampus, sesuai dengan kegiatan usaha perikanan yang dikembangkan oleh pelaku utama dan pelaku usaha perikanan di lokasi praktik akhir taruna, termasuk di dalamnya adalah melakukan proses pendampingan berupa penyuluhan secara kontinu selama lebih kurang 3 (tiga) bulan masa praktik dilakukan. Metode penyuluhan perikanan yang dilaksanakan mengandung tiga unsur penting yang meliputi aspek teknologi perikanan, aspek pengembangan ekonomi bisnis, dan aspek penyuluhan perikanan. Metode penyuluhan tersebut dilakukan dengan menggunakan metode kolam percontohan (dempond), demonstrasi cara (demcar) yang berkaitan dengan teknologi perikanan, serta pendampingan peran dan fungsi kelompok dalam meningkatkan kualitas pengelolaan kelompok sesuai dengan usaha perikanan yang dilakukan.

PermenKP No. 30 (2014) tentang Mekanisme Kerja dan Metode Penyuluhan Perikanan menyebutkan bahwa metode penyuluhan perikanan adalah cara yang digunakan untuk mendekatkan penyuluh perikanan dengan sasaran penyuluhan, sedangkan materi penyuluhan adalah bahan penyuluhan yang akan disampaikan oleh para penyuluh kepada pelaku utama dan pelaku usaha dalam berbagai bentuk yang meliputi informasi, teknologi, rekayasa sosial, manajemen, ekonomi, hukum, dan kelestarian lingkungan. Sasaran penyuluhan merupakan pelaku utama kegiatan per- 
ikanan seperti nelayan, pembudidaya ikan, pengolah ikan, pengolah garam, dan pengelola konservasi beserta keluarga intinya (Undang-Undang No 16 2006). Metode ini bertujuan untuk mempercepat dan mempermudah penyampaian materi serta meningkatkan efektivitas dan efisiensi penyelenggaraan penyuluhan perikanan.

Dalam petunjuk teknis percontohan perikanan budidaya melalui tugas pembantuan tahun 2015 disebutkan bahwa pembudidaya ikan sebagai pelaku utama dan pelaku usaha yang bergabung dalam kelembagaan kelompok pembudidaya ikan (Pokdakan) mempunyai peran penting sebagai ujung tombak dalam upaya peningkatan produksi di lapangan, dengan demikian kelompok dituntut agar mampu, tangguh, dinamis, dan mandiri (Direktorat Jenderal Perikanan Budidaya 2015). Kegiatan percontohan perikanan budidaya diharapkan dapat menjadi tontonan, tuntunan, dan teladan bagi kelompok perikanan budidaya dalam melakukan pengembangan usaha perikanan budidaya.

Demonstrasi cara merupakan metode dan teknik penyuluhan yang dilakukan dengan cara peragaan. Kegiatan demonstrasi dilakukan dengan maksud agar memperlihatkan suatu inovasi baru kepada sasaran secara nyata atau konkret. Melalui kegiatan demonstrasi, sasaran (audience) diajarkan mengenai keterampilan, memperagakan cara kerja teknik-teknik baru termasuk keunggulannya untuk menyempurnakan cara lama. Sedangkan pendampingan administrasi kelompok adalah meningkatkan kemampuan dan keterampilan pelaku utama dalam kelompok sehingga dapat mengelola organisasi kelompoknya dengan baik dan benar (PerMenKP No 22 2014).

Penilaian sejauh mana efektivitas metode penyuluhan perikanan yang diterapkan taruna pada praktik akhir perlu dilakukan, untuk melihat bagaimana operasional program dan hasil atau dampak yang dicapai sebagai bahan perbaikan selanjutnya. Penilaian ini dilakukan dengan melakukan evaluasi pemilihan metode penyuluhan perikanan, yang berfungsi: (a) memberikan informasi kinerja dan pencapaian tujuan praktik akhir, (b) memberikan sumbangan dan klarifikasi terhadap nilai-nilai yang mendasari pemilihan metode praktik akhir, dan (c) memberikan rekomendasi dan perumusan ulang metode penyuluhan perikanan yang dilakukan taruna. Adanya kesenjangan di tingkat pelaku utama yang tergabung dalam kelompok-kelompok pembudidaya ikan baik dalam hal rendahnya pemahaman tentang inovasi teknologi baru di bidang perikanan, pengelolaan dan manajemen bisnis perikanan yang dilakukan maupun pemahaman kelompok dalam mengelola ad- 
ministrasi kelompok dan organisasinya, menjadi satu permasalahan utama secara umum ketika taruna akan melaksanakan praktik akhir.

\section{Model Evaluasi CIPP (Context, Input, Process, Product)}

Model evaluasi CIPP ini pada awalnya digunakan untuk mengevaluasi ESEA (the Elementary and Secondary Education Act). CIPP merupakan singkatan dari, context evaluation: evaluasi terhadap konteks, input evaluation: evaluasi terhadap masukan, process evaluation: evaluasi terhadap proses, dan product evaluation: evaluasi terhadap hasil (Stufflebeam 2003). Keempat singkatan dari CIPP tersebut itulah yang menjadi komponen evaluasi. Model evaluasi CIPP dalam pelaksanaannya lebih banyak digunakan oleh para evaluator, hal ini dikarenakan model evaluasi ini lebih komprehensif jika dibandingkan dengan model evaluasi lainnya.

\section{Tujuan Praktik Akhir Taruna}

Tujuan praktik akhir taruna sebagaimana tercantum dalam, yang akan menjadi fokus evaluasi dengan menggunakan konsep CIPP adalah agar taruna mampu menyusun rencana pengembangan usaha suatu komoditas perikanan dalam suatu wilayah (kecamatan) dengan konsep sistem bisnis perikanan dan taruna mampu mempraktekkan secara komprehensif semua ilmu (penyuluhan perikanan, teknologi perikanan, sosial dan ekonomi perikanan) yang telah diperoleh untuk mengembangkan atau menggerakkan kegiatan sistem usaha perikanan (Anon 2018). Selain itu, kemampuan yang diharapkan dari taruna dalam kegiatan PA ini adalah: 1) kemampuan untuk mengidentifikasi potensi dan permasalahan sumber daya alam, suberdaya manusia dan kondisi usaha perikanan di suatu wilayah dengan konsep sistem bisnis perikanan; 2) kemampuan untuk menentukan pilihan kegiatan penyuluhan perikanan sebagai upaya pemecahan masalah; 3) kemampuan menggali dan memanfaatkan komunikasi dan informasi serta menumbuhkan jejaring kerja sama; serta 4) kemampuan untuk mendampingi pelaku utama (nelayan, pembudidaya ikan, pengolah ikan, pedagang ikan) dalam memanajemen usaha yang layak, serta mengakses permodalan.

Berdasarkan tujuan PA tersebut maka tujuan evaluasi penerapan metode penyuluhan perikanan pada program praktik akhir dengan menggunakan CIPP ini adalah:

1. Menilai dan mengukur komponen context (konteks), input (masukan), process (proses), dan product (produk, output dan dampak) penerapan metode penyuluhan perikanan program praktik akhir taruna pada Tahun Akademik 2018/2019. 
2. Menyusun konsep rekomendasi untuk perbaikan (improve) penerapan metode penyuluhan perikanan program praktik akhir taruna Tahun Akademik 2018/2019.

\section{METODE}

Lokasi penelitian berada di Kabupaten Majalengka dan Kota Banjar yang merupakan lokasi Praktik Akhir tahun 2019. Data diambil pada Bulan April-Mei 2019. Populasi penelitian adalah anggota-anggota kelompok pembudidaya di 9 (sembilan) kecamatan di Kabupaten Majalengka dan 4 (empat) kecamatan di Kota Banjar, sehingga total responden sejumlah 94 orang.

Data primer diperoleh melalui kuesioner yang disebarkan kepada responden, dilengkapi dengan wawancara mendalam (depth interview) dengan sejumlah narasumber dan observasi. Kuesioner berisi sejumlah pernyataan dan pertanyaan yang berkaitan dengan komponen context, input, process, dan product penerapan metode penyuluhan perikanan pada program praktik akhir meliputi komponen, Indikator, pertanyaan pengukur indikator dan pengukuran menggunakan skala ordinal. Data sekunder diperoleh dari dokumen dan pustaka berbagai sumber yang berhubungan dengan tujuan evaluasi.

Data dianalisis dengan menggunakan analisis statistika deskriptif berupa tabulasi, distribusi frekuensi, menghitung rataan (mean), dan pengelompokan berdasarkan skala ordinal yang telah ditentukan. Prosedur analisis data memperhatikan berbagai hal berupa data informasi yang terkumpul dan kemudian diidentifikasi dan ditabulasikan untuk skoring. Data peubah tersebut diolah dan dianalisis dengan menggolongkan, menghitung jawaban, dan memersentasekan berdasarkan golongan jawaban. Keseluruhan data diolah dengan menggunakan tabulasi distribusi frekuensi dan nilai tengah yang kemudian dianalisis secara deskriptif dan dinarasikan (Sugiyono 2013).

\section{HASIL DAN PEMBAHASAN}

Hasil

\section{Evaluasi Konteks}

Evaluasi Konteks berfungsi untuk mendefinisikan situasi lingkungan yang relevan dan alasan untuk menentukan tujuan, mengidentifikasi kebutuhan, dan menentukan strategi (Stufflebeam dan Shinkfield 2007). Komponen yang diamati dalam evaluasi konteks ini adalah: (1) relevansi penerapan metode penyuluhan perikanan dengan kebutuhan; (2) relevansi program (penerapan metode penyuluhan perikanan) dengan masalah; (3) relevansi program (metode penyuluhan perikanan) dengan potensi (aset); dan (4) relevansi tujuan penerapan metode penyuluhan perikanan. 
Tabel 1. Distribusi Hasil Evaluasi Konteks Penerapan Metode Penyuluhan Perikanan

\begin{tabular}{|c|c|c|c|}
\hline Komponen Konteks & Kategori & $\begin{array}{l}\text { Jumlah } \\
\text { (orang) }\end{array}$ & $\begin{array}{c}\text { Persentase } \\
(\%)\end{array}$ \\
\hline \multirow{3}{*}{$\begin{array}{l}\text { Relevansi Program Penerapan } \\
\text { Metode PP dengan Kebutuhan } \\
\text { (rataan skor } 2,77 \text { ) }\end{array}$} & Rendah $(1,00-1,66)$ & 0 & 0 \\
\hline & Sedang $(1,67-2,32)$ & 7 & 7,45 \\
\hline & Tinggi $(2,33-3,00)$ & 87 & 92,55 \\
\hline \multirow{3}{*}{$\begin{array}{l}\text { Relevansi Program Penerapan } \\
\text { Metode PP dengan Masalah } \\
\text { (rataan skor 2,80) }\end{array}$} & Rendah $(1,00-1,66)$ & 1 & 1,06 \\
\hline & Sedang $(1,67-2,32)$ & 11 & 11,70 \\
\hline & Tinggi $(2,33-3,00)$ & 82 & 87,23 \\
\hline \multirow{3}{*}{$\begin{array}{l}\text { Relevansi Program Penerapan } \\
\text { Metode PP dengan Potensi/ } \\
\text { Aset (rataan skor } 2,88)\end{array}$} & Rendah $(1,00-1,66)$ & 0 & 0 \\
\hline & Sedang $(1,67-2,32)$ & 2 & 2,13 \\
\hline & Tinggi $(2,33-3,00)$ & 92 & 97,87 \\
\hline \multirow{3}{*}{$\begin{array}{l}\text { Relevansi Tujuan Program } \\
\text { Penerapan PP } \\
\text { (rataan skor 2,30) }\end{array}$} & Rendah $(1,00-1,66)$ & 0 & 0 \\
\hline & Sedang $(1,67-2,32)$ & 78 & 17,02 \\
\hline & Tinggi $(2,33-3,00)$ & 16 & 82,98 \\
\hline \multirow{3}{*}{$\begin{array}{l}\text { Rataan Skor Konteks } \\
\text { (Kategori): } 2,69\end{array}$} & Rendah $(1,00-1,66)$ & 0,25 & 0,27 \\
\hline & Sedang $(1,67-2,32)$ & 9 & 9,57 \\
\hline & Tinggi $(2,33-3,00)$ & 84,75 & 90.16 \\
\hline
\end{tabular}

Keterangan: $\mathrm{n}=94$

Tabel 1 menunjukkan bahwa relevansi program penerapan metode PP dengan kebutuhan pelaku utama (rataan skor 2,77), relevansi program penerapan metode PP dengan masalah pelaku utama (rataan skor 2,30), dan relevansi program penerapan metode PP dengan potensi/ aset yang dimiliki oleh pelaku utama (rataan skor 2,88) berada pada kategori tinggi $(2,33-3,00)$, sedangkan relevansi tujuan program penerapan PP (rataan skor 2,30) berada pada kategori sedang (1,67-2,32). Hal ini menunjukkan bahwa distribusi hasil evaluasi konteks penerapan metode penyuluhan perikan- an secara keseluruhan dengan nilai rataan skor konteks sebesar 2,69, masuk dalam kategori tinggi $(2,33-3,00)$.

\section{Evaluasi Input}

Boyle (1981) mengemukakan bahwa evaluasi input berfungsi untuk menentukan desain yang sesuai untuk mencapai tujuan program dalam hal biaya dan manfaat potensial. Biaya dan manfaat didefinisikan dalam istilah baik mauneter dan sosial. Adapun komponen yang diamati pada evaluasi input adalah: (1) Peserta sebagai sasaran penerapan metode penyuluhan perikanan Praktik 


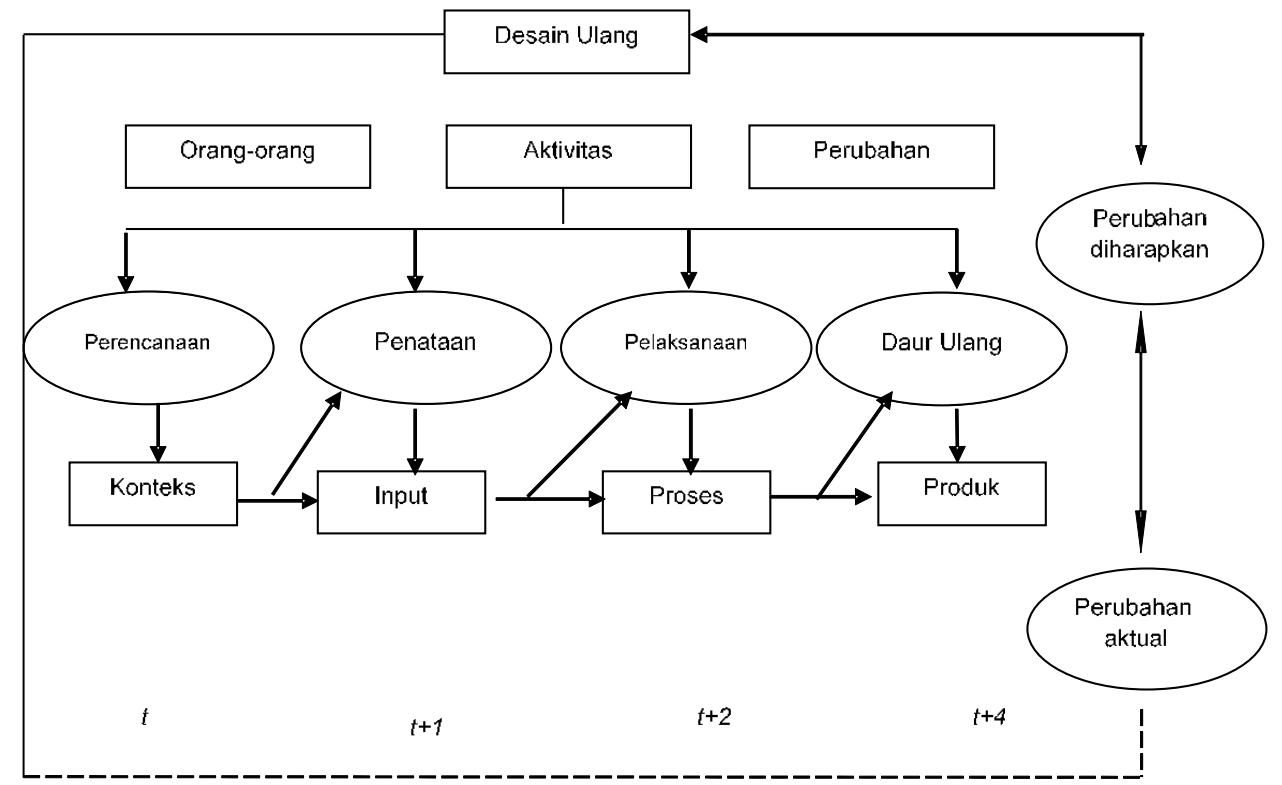

Gambar 1. Implikasi Hasil Evaluasi dan Rekomendasi Perbaikan (Boyle,1981)

Tabel 2. Distribusi Hasil Evaluasi Input Penerapan Metode Penyuluhan Perikanan

\begin{tabular}{|c|c|c|c|}
\hline Komponen Input & Kategori & $\begin{array}{l}\text { Jumlah } \\
\text { (orang) }\end{array}$ & $\begin{array}{c}\text { Persentase } \\
\text { (\%) }\end{array}$ \\
\hline \multirow{3}{*}{$\begin{array}{l}\text { Jelaku Utama sebagai } \\
\text { jasaran Program penerapan } \\
\text { netode PP (rataan skor 2,52) }\end{array}$} & Rendah $(1,00-1,66)$ & 0 & 0 \\
\hline & Sedang $(1,67-2,32)$ & 16 & 17,02 \\
\hline & Tinggi $(2,33-3,00)$ & 78 & 82,97 \\
\hline \multirow{3}{*}{$\begin{array}{l}\text { Taruna dan penyuluh } \\
\text { rataan skor } 2,55)\end{array}$} & Rendah $(1,00-1,66)$ & 20 & 21,28 \\
\hline & Sedang $(1,67-2,32)$ & 30 & 31,91 \\
\hline & Tinggi $(2,33-3,00)$ & 44 & 46,81 \\
\hline \multirow{3}{*}{$\begin{array}{l}\text { Jarana dan Prasarana } \\
\text { rataan skor } 2,45)\end{array}$} & Rendah $(1,00-1,66)$ & 4 & 4,26 \\
\hline & Sedang $(1,67-2,32)$ & 36 & 38,29 \\
\hline & Tinggi $(2,33-3,00)$ & 54 & 57,45 \\
\hline \multirow{3}{*}{$\begin{array}{l}\text { Prosedur/Aturan } \\
\text { rataan skor 2,75) }\end{array}$} & Rendah $(1,00-1,66)$ & 0 & 0 \\
\hline & Sedang $(1,67-2,32)$ & 11 & 11,70 \\
\hline & Tinggi $(2,33-3,00)$ & 83 & 88,29 \\
\hline \multirow{3}{*}{$\begin{array}{l}\text { Zataan Skor Input } \\
\text { 'Kategori): } 2,57\end{array}$} & Rendah $(1,00-1,66)$ & 6 & 6,3 \\
\hline & Sedang $(1,67-2,32)$ & 23 & 24,5 \\
\hline & Tinggi $(2,33-3,00)$ & 65 & 69,2 \\
\hline
\end{tabular}


Tabel 3. Distribusi Hasil Evaluasi Proses Penerapan Metode Penyuluhan Perikanan

\begin{tabular}{|c|c|c|c|}
\hline Komponen Proses & Kategori & $\begin{array}{l}\text { Jumlah } \\
\text { (orang) }\end{array}$ & $\begin{array}{l}\text { Persentase } \\
\text { (\%) }\end{array}$ \\
\hline \multirow{3}{*}{$\begin{array}{l}\text { Keterlibatan dan partisipasi } \\
\text { pelaku utama } \\
\text { (rataan skor } 3,00)\end{array}$} & Rendah $(1,00-1,66)$ & 1 & 1,06 \\
\hline & Sedang $(1,67-2,32)$ & 40 & 42,55 \\
\hline & Tinggi $(2,33-3,00)$ & 53 & 56,38 \\
\hline \multirow{3}{*}{$\begin{array}{l}\text { Ketepatan jadwal dan } \\
\text { rencana } \\
(\text { rataan skor 3,00) }\end{array}$} & Rendah $(1,00-1,66)$ & 5 & 5,32 \\
\hline & Sedang $(1,67-2,32)$ & 18 & 19,15 \\
\hline & Tinggi $(2,33-3,00)$ & 71 & 75,53 \\
\hline \multirow{3}{*}{$\begin{array}{l}\text { Keterlibatan dan peran taruna } \\
\text { /penyuluh } \\
\text { (rataan skor } 2,75 \text { ) }\end{array}$} & Rendah $(1,00-1,66)$ & 19 & 20,21 \\
\hline & Sedang $(1,67-2,32)$ & 19 & 20,21 \\
\hline & Tinggi $(2,33-3,00)$ & 56 & 59,57 \\
\hline \multirow[t]{3}{*}{$\begin{array}{l}\text { Penyelenggaraan kegiatan } \\
\text { (rataan skor } 3,00 \text { ) }\end{array}$} & $\begin{array}{l}\text { Rendah/Tidak Baik }(1,00- \\
1,66)\end{array}$ & 0 & 0 \\
\hline & $\begin{array}{c}\text { Sedang/Kurang Baik }(1,67- \\
2,32)\end{array}$ & 14 & 14,89 \\
\hline & Tinggi/Baik $(2,33-3,00)$ & 80 & 85,11 \\
\hline \multirow{3}{*}{$\begin{array}{l}\text { Penerapan Prosedur/Aturan } \\
\text { (rataan skor } 2,45 \text { ) }\end{array}$} & Rendah $(1,00-1,66)$ & 0 & 0 \\
\hline & Sedang $(1,67-2,32)$ & 27 & 28,72 \\
\hline & Tinggi $(2,33-3,00)$ & 67 & 71,28 \\
\hline \multirow{3}{*}{$\begin{array}{l}\text { Hambatan/Masalah Program } \\
\text { (rataan skor 2,30) }\end{array}$} & Tinggi $(1,00-1,66)$ & 8 & 8,51 \\
\hline & Sedang $(1,67-2,32)$ & 55 & 58,51 \\
\hline & Rendah $(2,33-3,00)$ & 31 & 32,98 \\
\hline \multirow{3}{*}{$\begin{array}{l}\text { Rataan Skor Proses } \\
\text { (Kategori): } 2,75\end{array}$} & Rendah $(1,00-1,66)$ & 5,5 & 5,85 \\
\hline & Sedang $(1,67-2,32)$ & 28,83 & 30,67 \\
\hline & Tinggi $(2,33-3,00)$ & 59,67 & 63,48 \\
\hline
\end{tabular}

Keterangan: $\mathrm{n}=94$

Akhir; (2) Taruna dan penyuluh yang terlibat dalam program; (3) Sarana prasarana; dan (4) Prosedur dan peraturan.

Tabel 2 menunjukkan bahwa komponen input yang terdiri dari pelaku utama sebagai sasaran program penerapan metode PP (rataan skor 2,52), taruna dan penyuluh (rataan skor 2,55), sarana dan prasarana (rataan skor 2,45), dan prosedur/aturan (rataan skor 2,75), sehingga seluruh komponen input yang diukur berada pada kategori tinggi $(2,33$ $3,00)$. Hal ini menunjukkan bahwa distribusi hasil evaluasi input penerapan metode penyuluhan perikanan secara keseluruhan dengan nilai rataan skor input 
sebesar 2,57, masuk dalam kategori tinggi $(2,33-3,00)$.

\section{Evaluasi Proses}

Evaluasi proses berfungsi untuk mengidentifikasi "cacat" dalam desain prosedural program atau pelaksanaannya dengan terus memantau pencapaian tujuan kegiatan belajar (Boyle 1981). Komponen yang diamati dalam evaluasi proses adalah: (1) Keterlibatan dan partisipasi peserta/pelaku utama; (2) Ketepatan kegiatan dengan rencana/jadwal; (3) Peran Taruna dan Penyuluh; (4) penyelenggaraan Program/Kegiatan (Materi, Metode, dan Media); (5) penerapan prosedur dan peraturan; serta (6) hambatan/permasalahan program.

Tabel 3 menunjukkan bahwa komponen proses penerapan metode penyuluhan perikanan yang terdiri dari keterlibatan dan partisipasi peserta/pelaku utama (rataan skor 3,00), ketepatan kegiatan dengan rencana/jadwal (rataan skor 3,00), keterlibatan dan peran taruna/ penyuluh (rataan skor 2,75), penyelenggaraan program/kegiatan (Materi, Metode, dan Media) (rataan skor 3,00), dan penerapan prosedur dan peraturan (rataan skor 2,45), berada pada kategori tinggi $(2,33-3,00)$, sedangkan komponen proses mengenai hambatan/permasalahan program (rataan skor 2,30) berada pada kategori sedang (1,67-2,32), Hal ini menunjukkan bahwa distribusi hasil evaluasi proses penerapan metode penyuluhan perikanan secara keseluruhan dengan nilai rataan skor proses sebesar 2,75, termasuk dalam kategori tinggi $(2,33-3,00)$.

\section{Evaluasi Produk}

Evaluasi produk mengukur dan menafsirkan hasil pada akhir program serta pada setiap tahapan selama pelaksanaan, dalam rangka memberikan tolok ukur bagi upaya pemrograman di masa depan (Boyle 1981). Komponen yang diamati dalam evaluasi produk kegiatan penerapan metode penyuluhan perikanan pada praktik akhir taruna TA. 2018/2019 ini adalah: (1) Peningkatan pengetahuan pelaku utama dalam hal peran dan fungsi kelompok seperti administrasi dan manajemen kelompok; (2) Peningkatan pengetahuan pelaku utama melalui dempond (kolam percontohan) dan demcar (demonstrasi cara) untuk mentransfer teknologi baru perikanan; (3) Peningkatan keterampilan peserta dalam aspek teknologi dan manajemen usaha pelaku utama; (4) Penerapan materi pasca program yaitu penerapan inovasi teknologi dan manajemen perikanan dalam usaha pelaku utama; (5) Peningkatan produktivitas usaha budidaya pelaku utama; (6) Keberlanjutan usaha budidaya pelaku utama; (7) Menumbuhkembangkan kewirausa- 
Tabel 4. Distribusi Hasil Evaluasi Produk Penerapan Metode Penyuluhan Perikanan

\begin{tabular}{|c|c|c|c|}
\hline Komponen Produk & Kategori & $\begin{array}{l}\text { Jumlah } \\
\text { (orang) }\end{array}$ & $\begin{array}{c}\text { Persentase } \\
\text { (\%) }\end{array}$ \\
\hline \multirow{3}{*}{$\begin{array}{l}\text { Peningkatan pengetahuan } \\
\text { dalam kelompok } \\
\text { (rataan skor } 2,15 \text { ) }\end{array}$} & Rendah $(1,00-1,66)$ & 22 & 23,40 \\
\hline & Sedang $(1,67-2,32)$ & 16 & 17,02 \\
\hline & Tinggi $(2,33-3,00)$ & 56 & 59,57 \\
\hline \multirow{3}{*}{$\begin{array}{l}\text { Peningkatan pengetahuan } \\
\text { dalam teknologi } \\
\text { (rataan skor } 2,35 \text { ) }\end{array}$} & Rendah $(1,00-1,66)$ & 22 & 23,40 \\
\hline & Sedang $(1,67-2,32)$ & 19 & 20.21 \\
\hline & Tinggi $(2,33-3,00)$ & 53 & 56,38 \\
\hline \multirow{3}{*}{$\begin{array}{l}\text { Peningkatan keterampilan } \\
\text { (rataan skor } 2,70 \text { ) }\end{array}$} & Rendah $(1,00-1,66)$ & 24 & 25,53 \\
\hline & Sedang $(1,67-2,32)$ & 15 & 15,96 \\
\hline & Tinggi $(2,33$ - 3,00) & 55 & 58,51 \\
\hline \multirow{3}{*}{$\begin{array}{l}\text { Penerapan pasca program } \\
\text { (rataan skor } 1,85)\end{array}$} & Rendah $(1,00-1,66)$ & 26 & 27,66 \\
\hline & Sedang $(1,67$ - 2,32) & 30 & 31,91 \\
\hline & Tinggi $(2,33-3,00)$ & 38 & 40,43 \\
\hline \multirow{3}{*}{$\begin{array}{l}\text { Peningkatan produktivitas } \\
\text { (rataan skor } 2,05 \text { ) }\end{array}$} & Rendah $(1,00-1,66)$ & 6 & 6,38 \\
\hline & Sedang $(1,67-2,32)$ & 74 & 78,72 \\
\hline & Tinggi/Baik $(2,33-3,00)$ & 14 & 14,89 \\
\hline \multirow{3}{*}{$\begin{array}{l}\text { Keberlanjutan kegiatan } \\
\text { (rataan skor } 2,20)\end{array}$} & Tinggi $(1,00-1,66)$ & 4 & 4,26 \\
\hline & Sedang $(1,67$ - 2,32) & 66 & 70,21 \\
\hline & Rendah $(2,33-3,00)$ & 24 & 25,53 \\
\hline \multirow{3}{*}{$\begin{array}{l}\text { Kondisi wirausaha } \\
\text { (rataan skor 1,90) }\end{array}$} & Tinggi $(1,00-1,66)$ & 5 & 5,32 \\
\hline & Sedang $(1,67$ - 2,32) & 44 & 46,81 \\
\hline & Rendah $(2,33-3,00)$ & 45 & 47,87 \\
\hline \multirow{3}{*}{$\begin{array}{l}\text { Kerjasama/Kemitraan } \\
\text { (rataan skor 2,00) }\end{array}$} & Tinggi $(1,00-1,66)$ & 13 & 13,83 \\
\hline & Sedang $(1,67-2,32)$ & 72 & 76,60 \\
\hline & Rendah $(2,33-3,00)$ & 9 & 9,57 \\
\hline \multirow{3}{*}{$\begin{array}{l}\text { Rataan Skor Produk } \\
\text { (Kategori): 2,15 }\end{array}$} & Rendah $(1,00-1,66)$ & 15,25 & 16,22 \\
\hline & Sedang $(1,67-2,32)$ & 42,00 & 46,68 \\
\hline & Tinggi $(2,33-3,00)$ & 36,75 & 39,09 \\
\hline
\end{tabular}

Keterangan: $\mathrm{n}=94$

haan yang jauh lebih baik; dan (8) Menjalin kerja sama/kemitraan dengan pihak lain seperti antar kelompok yang ada, peneliti, lembaga pemerintah, dan swasta. 
Data pada Tabel 4 menunjukkan bahwa data komponen produk penerapan metode penyuluhan perikanan yang terdiri dari peningkatan pengetahuan pelaku utama melalui dempond (kolam percontohan) dan demcar (demonstrasi cara) untuk mentransfer teknologi baru perikanan (rataan skor 2,35), dan peningkatan keterampilan peserta dalam aspek teknologi dan manajemen usaha pelaku utama (rataan skor 2,70) berada pada kategori tinggi $(2,33-3,00)$, sedangkan peningkatan pengetahuan pelaku utama dalam hal peran dan fungsi kelompok seperti administrasi dan manajemen kelompok (rataan skor 2,15), penerapan materi pasca program yaitu penerapan inovasi teknologi dan manajemen perikanan dalam usaha pelaku utama (rataan skor 1,85), peningkatan produktivitas usaha budidaya pelaku utama (rataan skor 2,05), keberlanjutan usaha budidaya pelaku utama (rataan skor 2,20), menumbuhkembangkan kewirausahaan yang jauh lebih baik (rataan skor 1,90), serta menjalin kerjasama/ kemitraan dengan pihak lain seperti antar kelompok yang ada, peneliti, lembaga pemerintah dan swasta (rataan skor 2,00), berada pada kategori sedang (1,67-2,32). Hal ini menunjukkan bahwa distribusi hasil evaluasi produk penerapan metode penyuluhan perikanan secara keseluruhan dengan nilai rataan skor proses sebesar 2,15 termasuk dalam kategori sedang $(1,67-2,32)$.

\section{Pembahasan}

Evaluasi Konteks

Tujuan pokok dari evaluasi konteks adalah menilai seluruh keadaan organisasi, mengidentifikasi kelemahan, menginventarisasi kekuatan yang dapat dimanfaatkan untuk menutupi kelemahan, mendiagnosis berbagai masalah yang dihadapi organisasi, dan mencari solusi (Ihwan Mahmudi 2011). Sejalan dengan pendapat tersebut, berdasarkan hasil analisis pada tabel 1 mengenai hasil evaluasi konteks penerapan metode penyuluhan perikanan pada saat Praktik Akhir (PA) taruna Jurusan Penyuluhan Perikanan Sekolah Tinggi Perikanan, terlihat bahwa secara umum konteks penerapan metode penyuluhan perikanan dengan menggunakan dempond, demcar, dan pendampingan peran fungsi kelompok pada praktik akhir taruna TA. 2018/2019 yang dilaksanakan di Kabupaten Majalengka dan Kota Banjar telah sesuai dengan apa yang ditetapkan (termasuk dalam kategori tinggi, dengan rataan skor 2,75). Keadaan ini menunjukkan bahwa program yang dijalankan telah relevan dengan kebutuhan pelaku utama. Hampir 92,55\% responden (pelaku utama perikanan) merespons bahwa penerapan metode penyuluhan perikanan yang telah dipilih pada 
saat praktik akhir oleh taruna Jurusan Penyuluhan Perikanan berupa demcar, dempond, dan pembinaan/pendampingan peran dan fungsi kelompok termasuk asistensi analisis usaha serta temu lapang dengan materi kegiatan pengembangan budidaya ikan air tawar memang sangat diperlukan dan sesuai (relevan) dengan kebutuhan mereka sebagai pelaku utama yang mengembangkan usaha budidaya ikan air tawar.

Hal yang masih dianggap kurang adalah terbatasnya jangkauan dempond, demcar, dan pendampingan peran dan fungsi kelompok, karena hanya beberapa kelompok saja yang dijadikan model mengingat taruna yang melakukan praktik akhir ini telah terbagi sesuai dengan lokasi yang telah ditentukan, sedangkan kelompok yang tidak terlibat langsung hanya dapat mengikuti proses difusi inovasi transfer teknologi yang dilakukan melalui temu lapang yang diselenggarakan pada akhir kegiatan praktek akhir taruna. Demikian juga dengan keikutsertaan pelaku utama langsung dalam merencanakan jenis kegiatan yang dilakukan oleh taruna masih belum secara aktif, tapi dilakukan melalui survei taruna pada saat praktik keahlian, memotret dan memilih metode penyuluhan perikanan untuk kaji terap yang akan dilaksanakan.

Relevansi program penerapan metode penyuluhan perikanan dengan masalah yang dihadapi oleh pelaku utama dan potensi sumber daya alam maupun sumber daya manusia tergolong baik (termasuk dalam kategori tinggi, dengan rataan skor 2,80). Responden menilai metode penyuluhan perikanan yang dirancang, berupa dempond (kolam pencontohan), demonstrasi cara serta pendampingan peran dan fungsi kelompok dalam mengaktifkan fungsi kelompok, sesuai dengan masalah yang dihadapi pelaku utama yang berada pada kelompok pembudidaya di Kabupaten Majalengka dan Kota Banjar.

Demikian juga dengan relevansi antara penerapan metode penyuluhan perikanan dengan potensi kedua wilayah kegiatan praktik akhir taruna sangat baik dengan rataan skor 2,88. Pelaku utama yang berada di kedua lokasi ini melakukan usaha budidaya ikan air tawar baik pembenihan maupun pembesaran dengan komoditas ikan mas, ikan lele, ikan gurami dan beberapa jenis ikan air tawar lainnya serta usaha pengolahan ikan sesuai dengan potensi perikanan yang ada di lokasi ini. Penerapan metode penyuluhan perikanan yang dipilih oleh taruna sangat mendukung memperbaiki teknologi budidaya yang dipergunakan pelaku utama.

Komponen konteks yang masih dianggap kurang dalam penerapan metode penyuluhan perikanan ini adalah keterlibatan peserta dalam penentuan tujuan dan target program/kegiatan (terma- 
suk dalam kategori sedang, dengan rataan skor 2,30). Responden menilai bahwa penentuan tujuan kurang partisipatif dan hanya dilakukan oleh taruna praktik akhir saja.

Seiring dengan pendapat Boyle (1981) bahwa dalam perencanaan program yang efektif bahwa seorang perencana harus dapat mempertimbangkan kebutuhan individu dalam melakukan usahanya sehingga akan mendapatkan kesesuaian dengan masalah yang dibutuhkan. Berdasarkan hasil pengumpulan data primer melalui kuesioner maupun wawancara dan observasi, penerapan metode penyuluhan perikanan yang digunakan oleh taruna telah mempertimbangkan kebutuhan individu pelaku utama dari sisi teknologi budidaya perikanannya, dan sarana prasarana yang menyesuaikan dengan kondisi di lapangan. dempond (kolam percontohan) dan demcar (demonstrasi cara) serta pendampingan fungsi kelompok sangat mengakomodir pemenuhan kebutuhan individu akan perlunya inovasi baru yang dapat diterapkan dalam usaha budidaya ikan mereka.

\section{Evaluasi Input}

Berdasarkan data hasil analisis CIPP pada tabel 2, terlihat bahwa secara umum input program penerapan metode penyuluhan perikanan praktik akhir taruna di Kabupaten Majalengka dan Kota
Banjar sangat baik sehingga menjamin efektivitas pelaksanaan program (termasuk dalam kategori tinggi, dengan rataan skor 2,49). Keadaan ini ditunjukkan dengan adanya beberapa hal yang mendukung seperti:

1. Adanya pelaku utama sebagai peserta yang mendukung dilakukannya program penerapan metode penyuluhan perikanan yang tergabung dalam kelompok perikanan budidaya dan partisipasi mereka dalam mengikuti rangkaian kegiatan penerapan metode penyuluhan perikanan dengan dempond, demcar, dan pendampingan peran dan fungsi kelompok. Responden merupakan para pelaku utama yang melakukan usaha pembenihan, pembesaran dengan sistem tradisional dan semi intensif maupun usaha pengolahan ikan.

2. Keterlibatan aktif taruna dan penyuluh serta pelaku utama di Kabupaten Majalengka dan Kota Banjar dalam program penerapan metode penyuluhan perikanan pada praktik akhir taruna. Terdapat 13 orang taruna sebagai fasilitator kegiatan praktik akhir di kedua lokasi praktek tersebut yang berkontribusi dalam penelitian ini.

Membandingkan hasil penelitian mengenai proses pembelajaran penerapan kurikulum berbasis KTSP dengan menggunakan metode CIPP dapat disim- 
pulkan bahwa pada proses pembelajaran ada suatu strategi yang dilakukan ditinjau dari segi input penerapan KTSP yang pada prinsipnya mengarah kepada pembenahan dari proses pembelajaran yang dilakukan (Syahril 2014). Demikian juga dengan kondisi pada evaluasi penerapan metode penyuluhan perikanan pada praktik akhir taruna ini diperlukan adanya strategi yang mengarah kepada dukungan komponen input yang masih dianggap kurang dalam program penerapan metode penyuluhan perikanan seperti ketersediaan dana yang minim dalam mencoba melakukan usaha budidaya sesuai dengan metode penyuluhan perikanan yang telah diberikan oleh taruna. Kondisi sarana prasarana pelaku utama masih dirasa kurang untuk dijadikan pendukung dalam mengaplikasikan teknologi budidaya yang ditransfer melalui metode penyuluhan perikanan yang digunakan, sehingga ke depan sangat dibutuhkan fasilitasi mengenai bantuan sarana maupun prasarana dari pemerintah setempat seperti Dinas Perikanan pada kedua lokasi bersangkutan. Responden menyatakan bahwa kegiatan ini sangat baik untuk pembekalan mereka dalam menjalankan usahanya, namun diperlukan sosialisasi aturan yang terkait agar dapat dijadikan acuan dalam pelaksanaannya.

\section{Evaluasi Proses}

Berdasarkan hasil analisis pada tabel 3, terlihat bahwa secara umum pelaksanaan penerapan metode penyuluhan perikanan dengan dempond, demcar dan pendampingan peran dan fungsi kelompok pada praktik akhir taruna tahun akademik 2018/2019 ini telah berjalan sangat baik sesuai dengan rencana yang telah disusun dan dapat mengoptimalkan input yang ada (termasuk dalam kategori tinggi, dengan rataan skor 2,49). Hal ini ditunjukkan dengan beberapa hal sebagai berikut:

1. Sebagian besar responden menyatakan bahwa mereka terlibat secara aktif dalam pelaksanaan program (kategori tinggi, rataan skor 3,00). Peserta sangat mendukung kegiatan yang ditunjukkan dengan tingkat kehadiran dan aktivitas partisipasi mereka selama dilakukannya demonstrasi cara, dempond (kolam percontohan, pendampingan fungsi kelompok maupun kegiatan pembinaan kelompok lainnya. Sebagian besar menyatakan mereka aktif mengemukakan saran dan pendapat serta pertanyaan-pertanyaan yang berkaitan dengan dempond, demcar. dan pendampingan peran dan fungsi kelompok. Demikian juga selalu berhubungan aktif dengan taruna praktik akhir dan penyuluh sebagai fasilitator di luar pertemuan rutin. 
2. Keterlibatan dan peran taruna sebagai fasilitator praktik akhir dan penyuluh di lapangan dinilai aktif dalam pelaksanaan kegiatan ini. Sebagian besar responden menyatakan bahwa fasilitator selalu hadir dalam setiap pertemuan, mampu menyampaikan materi penyuluhan berupa teori pembuatan dempond (kolam percontohan) dengan baik, membina dan mendampingi pelaku utama dalam mengarahkan mereka agar menjalankan kedelapan peran dan fungsi kelompok yaitu fungsi sebagai wahana pembelajaran, wahana kerja sama, unit penyedia sarana produksi, unit produksi usaha perikanan, unit pengolahan dan pemasaran, unit jasa penunjang, unit organisasi kegiatan bersama serta unit kegiatan swadaya dan swadana. Demikian juga pada saat mempraktikkan materi yang diberikan, mampu menjawab setiap pertanyaan responden dan memberikan contoh pelaksanaan kegiatan budidaya ikan air tawar melalui dempond, mampu menggunakan alat bantu dan sarana yang disediakan, mampu memberikan motivasi kepada para pelaku utama, mampu memberikan alternatif pemecahan masalah di lapangan, bersikap ramah, serta akrab dengan pelaku utama.

3. Penyelenggaraan penerapan metode penyuluhan perikanan dilaksanakan secara baik. Kualitas materi penyuluhan perikanan dengan metode dempond (kolam percontohan), demcar, pendampingan fungsi kelompok dengan ceramah maupun anjangsana dinilai baik oleh responden, dilakukan dengan sangat baik, menarik, partisipatif dan mampu meningkatkan pengetahuan dan keterampilan pelaku utama. Taruna praktik akhir juga menggunakan media penyuluhan perikanan seperti leaflet, brosur, folder, powerpoint presentation dan alat bantu nyata serta seluruh sarana yang ada dipergunakan secara optimal.

4. Penerapan metode penyuluhan perikanan ini dilaksanakan secara konsisten berdasarkan kesepakatan kedua belah pihak antara fasilitator yaitu taruna praktik akhir dan penyuluh dengan para pelaku utama sebagai sasaran.

Namun, terdapat beberapa permasalahan yang muncul seperti keadaan cuaca yang menyebabkan beberapa perubahan jadwal pelaksanaan kegiatan, penyesuaian jadwal pertemuan dengan waktu senggang pelaku utama serta permasalahan teknis lainnya, namun demikian secara umum dapat diatasi dan tidak menjadikan kendala yang besar. Pandangan dari sisi proses ini tentu saja harus diimbangi dengan keterlibatan dan partisipasi lembaga pendukung di 
wilayah Kabupaten Majalengka maupun Kota Banjar. Sesuai dengan hasil penelitian, bahwa pelaksanaan penyuluhan sebaiknya disesuaikan dengan potensi dan kebutuhan masing-masing daerah. Bagi daerah yang memiliki keunggulan komparatif dan kompetitif pada sub sektor peternakan, penyuluhan, dan pelatihan yang diberikan difokuskan pada sektor hilir atau pemasaran, sedangkan daerah yang tidak memiliki keunggulan komparatif dan kompetitif penyuluhan dan pelatihan difokuskan pada sektor hulu (Refita, Siregar, dan Suroso 2017).

\section{Evaluasi Produk}

Berdasarkan hasil analisis pada tabel 4, terlihat bahwa secara umum hasil evaluasi produk program penerapan metode penyuluhan perikanan berupa dempond, demcar dan pendampingan peran dan fungsi kelompok yang telah dilaksanakan dinilai masih belum mencapai tujuan dan target penerapan metode secara maksimal (termasuk dalam kategori sedang, dengan rataan skor 2,20 ). Keadaan ini menunjukkan bahwa program penerapan metode penyuluhan perikanan berupa dempond, demcar dan pendampingan peran dan fungsi kelompok pada taruna praktik akhir tahun 2019 telah berjalan namun belum mampu secara signifikan dan optimal meningkatkan pengetahuan dan keterampilan pelaku utama, meningkatkan produktivitas, dan mengembangkan jejaring usaha budidaya air tawar di kedua lokasi ini.

Melalui metode penyuluhan perikanan dempond (kolam percontohan) dan demonstrasi cara, pelaku utama mengetahui dan memahami, bahkan terdapat beberapa bagian yang parameternya menunjuk kepada kategori terampil melakukan dalam hal bagaimana cara mendesain dan membuat konstruksi kolam (tanah/terpal), mempersiapkan kolam budidaya dan sarananya, pemeliharaan induk, pemijahan induk ikan, penetasan larva, pemeliharaan larva, pemeliharaan benih, penyelenggaraan panen dan hal hal yang dilakukan setelah panen (pasca panen), meskipun tidak keseluruhan terampil namun diharapkan setelah melalui proses temu lapang proses difusi inovasi teknologi dapat diulang dan ditransfer kepada pelaku utama dan kelompok yang lainnya. Hal ini menjadi indikator yang baik bagi keberlanjutan penerapan metode penyuluhan perikanan dengan dempond, demcar dan pendampingan peran dan fungsi kelompok pada praktik akhir taruna. Komponen produk yang lain belum menunjukkan pencapaian maksimal antara lain dalam segi penerapan/ adopsi secara penuh oleh pelaku utama terkait inovasi teknologi maupun pendampingan fungsi kelompok karena adanya hal hal sebagai berikut: 
1. Pemahaman pelaku utama yang berbeda satu sama lain dalam menerima inovasi yang diberikan. Pelaku utama tergabung dalam kelompok belum menunjukkan kerjasama dan kekompakan yang optimal, yang disebabkan oleh terbatasnya waktu dan intensitas dalam pertemuan kelompok itu sendiri, belum memahami secara komprehensif mengenai tugas dan fungsi kelompok serta implementasi ke dalam kelompok.

2. Pelaku utama sudah mulai berminat untuk mengembangkan usahanya dengan mempergunakan inovasi teknologi yang diberikan melalui penerapan metode penyuluhan perikanan taruna, berusaha untuk membuka jejaring pemasaran yang lebih luas untuk hasil usahanya, walaupun belum dapat dinilai sampai di tahapan mana proses adopsi yang telah dilakukan pelaku utama.

Dampak dari penerapan metode penyuluhan perikanan dengan dempond, demcar dan pendampingan peran dan fungsi kelompok di kedua lokasi ini telah menunjukkan hasil, terbukti dari evaluasi pengetahuan dan keterampilan pelaku utama/responden pada pelaksanaan praktik akhir taruna di kedua lokasi ini menunjukkan nilai yang menggembirakan di mana tingkat perubahan sikap, pengetahuan dan keterampilan mereka menunjukkan nilai yang memuaskan, diserap dengan baik terutama pada segmen usaha pembenihan, pendederan dan pembesaran komoditas mayoritas ikan air tawar yang dikembangkan di kedua lokasi ini seperti Ikan Nila, Ikan Gurame, Ikan Lele. Hal tersebut sejalan dengan hasil penelitian yang menyatakan bahwa produktivitas yang tinggi berpengaruh terhadap meningkatnya kapasitas produksi dan nilai tambah produk untuk meningkatkan pendapatannya (Suriadi, Tripalupi, dan Sujana 2019).

Implikasi Hasil Evaluasi dan Rekomendasi Perbaikan

Boyle (1981) mengemukakan bahwa proses evaluasi berpuncak pada perbandingan hasil aktual dengan awal yang ditetapkan. Perbedaan tersebut diidentifikasi dan dimasukkan kembali ke sistem melalui desain ulang program yang mungkin dianggap sebagai kemampuan sistem untuk mengarahkan diri belajar dari kesalahan masa lalu dan meningkatkan kinerja sistem. Model evaluasi ini ditunjukkan pada gambar model evaluasi (Boyle 1981).

\section{Perbaikan Komponen Konteks}

Pelaksanaan kegiatan penerapan metode penyuluhan perikanan dengan cara dempond (kolam percontohan), demcar, pendampingan peran dan fungsi kelompok, dalam pelaksanaan survei dan persiapan kaji terap di lapangan 
memerlukan pelibatan pelaku utama yang lebih dominan seperti dalam identifikasi kebutuhan, penentuan tujuan, dan pengambilan keputusan terkait rencana penerapan metode penyuluhan perikanan yang cocok dengan usaha budidaya mereka.

\section{Perbaikan Komponen Input}

1. Pada tahap identifikasi dan penentuan sasaran sebagai obyek penerapan metode penyuluhan perikanan perlu diperhatikan tentang ketersediaan dana pengembangan usaha budidaya bagi pelaku utama sehingga dapat menjamin keberlanjutan usaha yang dilakukan, dalam hal ini diperlukan fasilitasi taruna dan penyuluh pada saat praktik akhir berlangsung terhadap Dinas Perikanan setempat atau lembaga lain yang terkait, sehingga dukungan terhadap usaha budidaya di kedua lokasi akan lebih baik.

2. Sosialisasi peraturan mengenai pengembangan usaha budidaya ikan perlu dilakukan sebagai acuan bagi pelaku utama dalam mengembangkan usahanya.

\section{Perbaikan Komponen Proses}

1. Diperlukan koordinasi waktu penyelenggaraan pendampingan maupun interaksi berkala penyuluhan perikanan yang dilakukan pada saat kegiatan dilaksanakan sehingga efektivitas dan efisiensi waktu akan lebih optimal.

2. Pemenuhan kebutuhan sarana produksi, penerapan metode penyuluhan perikanan dempond disesuaikan dengan kondisi usaha budidaya dan ketersediaan bahan di lapangan.

\section{Perbaikan Komponen Produk}

Diperlukan pendampingan secara intensif dan berkala dari penyuluh perikanan yang berada di kedua lokasi ini, khususnya dalam mengaktifkan peran dan fungsi kelompok serta pendampingan secara kontinu dalam penerapan teknologi baru perikanan dari penggunaan teknologi tradisional pada pemeliharaan budidaya ikannya menjadi pemeliharaan yang menggunakan cara semi intensif bahkan jika memungkinkan ke semi intensif. Diperlukan kerja sama dan koordinasi yang optimal untuk rencana aksi tindak lanjut sehingga pelaku utama dapat mencapai keberhasilan dalam pengembangan usaha budidayanya.

\section{SIMPULAN DAN SARAN \\ Simpulan}

Adapun kesimpulan dari hasil penelitian ini sebagai berikut:

1. Penerapan metode penyuluhan perikanan pada praktik akhir taruna berdasarkan hasil evaluasi secara umum telah menunjukkan performa yang baik. Hasil evaluasi terhadap kompo- 
nen konteks, input, dan proses secara umum telah berjalan baik.

2. Komponen yang masih ada kekurangan adalah pada komponen produk sebagai hasil kegiatan yang diprogramkan, terutama untuk pendampingan secara intensif dan berkala dari penyuluh perikanan yang berada di Kabupaten Majalengka dan Kota Banjar, terutama dalam mengaktifkan peran dan fungsi kelompok serta pendampingan secara kontinu dalam penerapan teknologi baru perikanan pasca kegiatan praktik akhir selesai.

3. Kerja sama dan koordinasi yang optimal diperlukan untuk rencana aksi tindak lanjut, sehingga akan lebih efektif dan efisien dalam memanfaatkan waktu yang ada serta pelaku utama dapat mencapai keberhasilan dalam pengembangan usahanya.

\section{Saran}

Rekomendasi untuk perbaikan program penerapan metode penyuluhan perikanan praktik akhir taruna di masa datang adalah:

1. Peningkatan keterlibatan pelaku utama dalam identifikasi kebutuhan metode, penentuan tujuan metode yang diambil, dan pengambilan keputusan terkait penerapan metode penyuluhan perikanan yang akan dilakukan taruna peserta praktik akhir beserta pelaku utama/responden yang terlibat.
2. Perlu adanya sosialisasi peraturanperaturan yang terkait dengan aturan pembudidayaan ikan serta keamanan hasil produk perikanan.

3. Adanya pendampingan intensif pasca program dari penyuluh perikanan baik dalam hal pengembangan peran dan fungsi kelompok maupun tentang inovasi teknologi budidaya ikan yang telah diberikan.

\section{PERSANTUNAN}

Ucapan terima kasih disampaikan kepada Ketua Jurusan Penyuluhan Perikanan, Sekolah Tinggi Perikanan, yang telah memfasilitasi pendanaan penelitian ini, kepada Kepala Dinas Perikanan Kabupaten Majalengka dan Kota Banjar, Jawa Barat beserta jajarannya, Penyuluh Perikanan PNS dan Penyuluh Perikanan Bantu (PPB) Kabupaten Majalengka dan Kota Banjar, Provinsi Jawa Barat serta pemangku kepentingan terkait, dan responden pelaku utama pada sepuluh kecamatan di Kabupaten Majalengka dan lima kecamatan di Kota Banjar.

\section{DAFTAR PUSTAKA}

Anon. 2018. Pedoman Umum Praktik Akhir Taruna pada Sekolah Tinggi Perikanan Jurusan Penyuluhan Perikanan Bogor. Bogor (ID): Jurusan Penyuluhan Perikanan, Sekolah Tinggi Perikanan. 
Boyle, Patrick Gerald. 1981. Planning Better Programs. New York: McGraw-Hill Book Company.

Direktorat Jenderal Perikanan Budidaya. 2015. Petunjuk Teknis Percontohan Perikanan Budidaya. Jakarta (ID): Kementerian Kelautan dan Perikanan.

Ihwan Mahmudi. 2011. "CIPP: Suatu Model Evaluasi Program Pendidikan." Jurnal At- Ta'dib 6(1):113-25. doi: 10.21111/attadib.v6i1.551.

PermenKP No. 30. 2014. tentang Mekanisme Kerja dan Metode Penyuluhan Perikanan. Indonesia.

PerMenKP No 22. 2014. Tentang Perlindungan Nelayan,

Pembudidaya Ikan, dan Petambak Garam Rakyat yang Terkena Bencana Alam. Indonesia.

Refita, Yelly, Hermanto Siregar, dan Arif Iman Suroso. 2017. "Evaluasi Program Sarjana Membangun Desa (SMD) dan Strategi Pengembangannya (Studi Kasus Provinsi Sumatera Barat, Jawa Barat dan Nusa Tenggara Barat)." Journal of Regional and Rural Development Planning 1(1):98. doi: 10.29244/jp2wd.2017.1.1.98-113.

Stufflebeam, Daniel L. 2003. "THE CIPP
Model for Evaluation: An Update, a Review of the Model's Development, a Checklist to Guide Implementation." in Annual Conference of the Oregon Program Evaluators Network.

Stufflebeam, Daniel L., dan Anthony J. Shinkfield. 2007. Evaluation theory, models, and applications. San Francisco (US): Jossey-Bass.

Sugiyono. 2013. Metodologi Penelitian Kombinasi (Mixed Methods). Bandung (ID): Alfabeta.

Suriadi, Gede, Lulup Endah Tripalupi, dan I. Nyoman Sujana. 2019. "Efektivitas Program Bantuan Pemerintah pada Kelompok Pengolah dan Pemasar (Poklahsar) Hasil Perikanan di Desa Bondalem Kecamatan Tejakula Kabupaten Buleleng." Jurnal Pendidikan Ekonomi Undiksha 11(2). doi: 10.23887/jjpe.v11i2.21609.

Syahril. 2014. "Evaluasi Model CIPP pada Implementasi KTSP Pembelajaran Pendidikan Jasmani." Jurnal Sport Pedagogy 4(1).

Undang-Undang No 16. 2006. tentang Sistem Penyuluhan Pertanian, Perikanan Dan Kehutanan. Indonesia. 